\title{
Myofibrillar protein oxidation affects filament charges, aggregation and water-holding
}

\section{Bao, Yulong}

2018-01

Bao , Y , Boeren , S \& Ertbjerg , P 2018 , ' Myofibrillar protein oxidation affects filament

charges, aggregation and water-holding ' , Meat Science , vol. 135 , pp. 102-108 . https://doi.org/10.1016/j.meatsci.2

http://hdl.handle.net/10138/308942

https://doi.org/10.1016/j.meatsci.2017.09.011

cc_by_nc_nd

acceptedVersion

Downloaded from Helda, University of Helsinki institutional repository.

This is an electronic reprint of the original article.

This reprint may differ from the original in pagination and typographic detail.

Please cite the original version. 


\title{
Myofibrillar protein oxidation affects filament charges, aggregation and water-
}

\section{holding}

Yulong Bao ${ }^{\mathrm{a}}$, Sjef Boeren ${ }^{\mathrm{b}}$, Per Ertbjerg ${ }^{\mathrm{a} *}$

${ }^{a}$ Department of Food and Environmental Sciences, University of Helsinki, 00014, Helsinki, Finland

${ }^{b}$ Laboratory of Biochemistry, Wageningen University, 6708WE, Wageningen, The Netherlands

*Corresponding author: Tel.: +358 503183909; E-mail address: per.ertbjerg@ helsinki.fi

\begin{abstract}
:
Hypochlorous acid $(\mathrm{HClO})$ is a strong oxidant that is able to mediate protein oxidation. In order to study the effect of oxidation on charges, aggregation and water-holding of myofibrillar proteins, extracted myofibrils were oxidized by incubation with different concentrations of $\mathrm{HClO}(0,1,5$, and $10 \mathrm{mM})$. Loss of free thiols, loss of histidine and formation of carbonyls were greater with increasing oxidation level and the particle size increased. Water-holding in the 5 and $10 \mathrm{mM} \mathrm{HClO}$ groups were greater than in the non-oxidized control. Isoelectric focusing (IEF) showed that the isoelectric point (pI) of oxidized proteins were lower compared to non-oxidized ones. The lower pI values of oxidized proteins suggests that oxidation increased the overall net negative charge of myofibrillar proteins solubilized for IEF. Here we propose a hypothesis that oxidation-induced increase in net negative charges is the driving force for improved water-holding in myofibrils, whereas protein cross-linking and aggregation have an opposing effect by decreasing the water-holding.
\end{abstract}

Keywords: carbonyls, free thiols, isoelectric point, particle size, histidine 


\section{Introduction}

Protein oxidation, which can readily occur in post-mortem muscle or during meat processing, involves modifications of some amino acid side chains, such as formation of cross-links and protein carbonylation (Estévez, 2011; Lund, Heinonen, Baron, \& Estevez, 2011). These modifications of proteins are able to affect meat quality and nutritional and health aspects (Estévez \& Luna, 2017). For example, it has been reported that protein oxidation leads to increased meat toughness (Bao \& Ertbjerg, 2015; Lund, Lametsch, Hviid, Jensen, \& Skibsted, 2007). However, the effect of protein oxidation on water-holding of meat, especially fresh meat, is unclear. Decker, Xiong, Calvert, Crum, \& Blanchard (1993) found decreased water-holding of gels made from oxidized turkey myofibrils. In support of their view, some authors (Estévez, 2011; Lund et al., 2011) have argued that protein oxidation leads to decreased water-holding. Recently, decreased water-holding of myofibril gels prepared from beef packaged with oxygen $(20-80 \%)$ has been reported (Wang, Luo, \& Ertbjerg, 2017).

In fresh raw meat oxidation-induced reactions are very complex. Lund et al. (2007) observed higher drip loss in high oxygen packaged pork as compared to vacuum packaged samples. In agreement, Delles \& Xiong (2014) found higher centrifugation loss in high oxygen packaged pork loins. However, other studies did not find a clear effect of high oxygen packaging on water-holding when compared to vacuum packaged beef (Clausen, Jakobsen, Ertbjerg, \& Madsen, 2009; Lindahl, Lagerstedt, Ertbjerg, Sampels, \& Lundström, 2010; Łopacka, Półtorak, \& Wierzbicka, 2017). In contrast, some studies even reported higher drip loss or purge loss in vacuum packaged meat compared to high oxygen packaged meat (Chen, Zhou, \& Zhang, 2015; Sekar, Dushyanthan, Radhakrishnan, \& Babu, 2006; Yang et al., 2016). Thus there is currently no general agreement about the effect of protein oxidation on water-holding of fresh meat.

To understand the effect of protein oxidation on water-holding of meat, it is important to know how protein oxidation affects physicochemical factors that contribute to water-holding. As reviewed by Puolanne \& 
Halonen (2010), various forces including electrostatic forces and osmotic forces are hypothesized to contribute to water-holding in meat. Both electrostatic forces and osmotic forces can affect swelling of myofibrils, and the swelling of myofibrils generally depends on two aspects: the net charges on myofilaments and structural constraints (e.g., Z-disks, actomyosin cross-bridges and intermediate filaments). Increased net charges are believed to induce swelling of myofibrils and lead to improved waterholding, while structural constraints prohibit unlimited swelling (Hamm, 1986; Offer \& Trinick, 1983).

In meat, oxidation is known to induce protein cross-links (Decker et al., 1993; Lund et al., 2007) and oxidation-induced disulfide cross-links between myosin molecules was suggested as a restricting factor that inhibit swelling of oxidized myofibrils during brine irrigation (Liu, Xiong, \& Chen, 2009). However, there is a lack of information about how oxidation can affect the net charges on myofilaments. Many of the amino acid sidechains can pick up or lose protons whereby the charges on the protein molecules are altered. The electrostatic properties of myofibrils are affected by charged amino acid side chains of proteins and peptides as those constituting the myosin and actin filaments. It has been suggested that oxidative modification of the side chains lead to modified electronic arrangement on myofilaments (Estévez, Ventanas, Heinonen, \& Puolanne, 2011) and the modification of filament charges was speculated to affect water-holding.

This paper aims to examine the effect of oxidation on the net charges of myofibrillar proteins by isoelectric focusing gel analysis, and to provide insight into the mechanism of oxidation-induced changes in waterholding and aggregation.

\section{Materials and methods}

\subsection{Extraction of myofibrils}


The pigs were slaughtered at a commercial slaughterhouse in Finland and muscles were excised at 24 hours postmortem, vacuum packaged and transported refrigerated to the lab. Each muscle was trimmed of visible connective tissue and external fat. Then the muscle was cut into small pieces (about $1 \mathrm{~cm}$ thick) and frozen stored at $-20^{\circ} \mathrm{C}$. Meat pieces were thawed before extraction of myofibrils. One part of meat samples was homogenized in four parts of cold MES buffer (100 mM KCl, $50 \mathrm{mM}$ MES (2-(NMorpholino) ethanesulfonic acid hydrate), $2 \mathrm{mM} \mathrm{MgCl}_{2}, 2 \mathrm{mM}$ EGTA (ethylene glycol tetraacetic acid), $\mathrm{pH}$ 5.5) for $40 \mathrm{~s}$ (two cycles of $20 \mathrm{~s}$ each) with a speed of 20,500 rpm using an IKA Ultra Turrax T25 homogenizer (Labortechnik, Staufen, Germany). The homogenate was passed through a metal mesh with an average pore size of $1 \mathrm{~mm}$ to remove any unbroken meat pieces and connective tissue. The filtrate was centrifuged at $1500 \mathrm{~g}$ for $15 \mathrm{~min}$ at $4{ }^{\circ} \mathrm{C}$. The pellet was washed twice with $20 \mathrm{~mL}$ of MES buffer followed by centrifugation at $1500 \mathrm{~g}$ for $15 \mathrm{~min}$ at $4{ }^{\circ} \mathrm{C}$.

\subsection{Oxidation of myofibrils}

Hypochlorous acid $(\mathrm{HClO})$ is a strong oxidant that is able to mediate protein oxidation (Pattison, Hawkins, and Davies, 2007). Although no obvious practical application exists, $\mathrm{HClO}$ has been used to induce protein oxidation in meat as an alternative to the Fenton reaction (Soglia, Petracci \& Ertbjerg, 2016). The myofibril pellet was suspended in four volumes of MES buffer. Aliquots of $0.5 \mathrm{~mL}$ of the myofibril suspension were added with different amounts of MES buffer and $\mathrm{NaClO}(100 \mathrm{mM}, \mathrm{pH} 8.0$, freshly made) to give a final concentration of $0,1,5$, and $10 \mathrm{mM} \mathrm{HClO}$ in $1 \mathrm{~mL}$ reaction mixture. A household $\mathrm{NaClO}$ solution was used and the concentration of $\mathrm{NaClO}$ was determined and adjusted to $100 \mathrm{mM}$ by measurement of the absorbance at $292 \mathrm{~nm}$ using an extinction coefficient of $350 \mathrm{M}^{-1} \mathrm{~cm}^{-1}$ (Morris, 1966) and the $\mathrm{pH}$ of the 100 $\mathrm{mM} \mathrm{NaClO}$ solution was adjusted to $\mathrm{pH} 8.0$ with acetic acid. The $\mathrm{pH}$ values of the reaction mixtures (myofibril suspension added with oxidant) were between 5.4 and 5.5. The oxidant exist mainly in the form 
of hypochlorous acid in the incubations as the $\mathrm{pH}$ is well below its $\mathrm{pKa}$ value of 7.5. The reaction mixtures were kept at cold room $\left(5^{\circ} \mathrm{C}\right)$. After overnight incubation, the reaction mixtures were centrifuged at 2400

g for 10 min to obtain myofibril pellets. The pellets were subsequently washed with MES buffer and centrifuged at $2400 \mathrm{~g}$ for $10 \mathrm{~min}$ at room temperature, and the washing was repeated once. The resultant myofibril pellet was used for determination of protein oxidation, particle size distribution, isoelectric focusing (IEF) gel analysis, amino acid analysis, and water-holding.

\subsection{Determination of protein oxidation}

Protein oxidation was measured as loss of free thiols and formation of carbonyl groups. For the free thiol content measurement, the pellet was suspended in $1 \mathrm{~mL}$ solution $(\mathrm{pH} 8.0)$ containing 5\% SDS and 0.1 M Tris-HCl. The suspensions were heated at $80^{\circ} \mathrm{C}$ for $30 \mathrm{~min}$ in a dry bath, and then cooled to room temperature followed by centrifugation at $10,000 \mathrm{~g}$ for $5 \mathrm{~min}$. The free thiol content in the supernatant was determined using a DTNB-based (DTNB, 5,5'-Dithiobis(2-nitrobenzoic acid) ) method (Ellman, 1959) with modifications described by Bao, Puolanne, \& Ertbjerg (2016). The carbonyl content was determined according to Soglia et al. (2016), exept that the myofibril pellet was suspended in $1 \mathrm{~mL}$ MES buffer and the centrifugation speed was $10,000 \mathrm{~g}$.

\subsection{Particle size}

The particle size distribution of the pellet suspended in MES buffer was determined by a Mastersizer 3000 (Malvern Instruments Ltd., Malvern, UK). Every suspension was analyzed five times using tap water as dispersant. The refractive index was set to 1.46 and the absorption coefficient to 0.01 , and the particles 
were considered as non-spherical. Volume weighted distribution and the following statistical parameters were reported:

$D(\mathrm{v}, 0.1)$ - the size of the particle for which $10 \%$ of the sample is below this size;

$D(\mathrm{v}, 0.5)$ - the size of the particle for which $50 \%$ of the sample is below this size;

$D(\mathrm{v}, 0.9)$ - the size of the particle for which $90 \%$ of the sample is below this size;

$D(3,2)$ - the surface area moment mean diameter, $D(3,2)=\sum \mathrm{n}_{\mathrm{i}} \mathrm{d}_{\mathrm{i}}^{3} / \sum \mathrm{n}_{\mathrm{i}} \mathrm{d}_{\mathrm{i}}{ }^{2}$, where $\mathrm{n}_{\mathrm{i}}$ is the number of particles with diameter $\mathrm{d}_{\mathrm{i}}$ and was calculated from the size distribution;

$D(4,3)$ - the volume moment mean diameter, $D(4,3)=\sum \mathrm{n}_{\mathrm{i}} \mathrm{d}_{\mathrm{i}}^{4} / \sum \mathrm{n}_{\mathrm{i}} \mathrm{d}_{\mathrm{i}}^{3}$, where $\mathrm{n}_{\mathrm{i}}$ is the number of particles with diameter $\mathrm{d}_{\mathrm{i}}$ and was calculated from the size distribution.

\subsection{IEF gels and western blot analysis}

The myofibril pellet was added with $1 \mathrm{~mL}$ of extraction solution ( $8 \mathrm{M}$ urea, $2 \mathrm{M}$ thiourea, $1 \%$ CHAPS) and kept at room temperature. After overnight extraction, the mixture was centrifuged at $10,000 \mathrm{~g}$ for 5 min. One part of the supernatant was mixed with one part of 2x sample buffer ( $8 \mathrm{M}$ urea, $2 \mathrm{M}$ thiourea, 1\% CHAPS, $80 \mathrm{mM}$ lysine, $15 \%$ glycerol) and centrifuged at 10,000 $\mathrm{g}$ for $5 \mathrm{~min}$. The resultant supernatant was loaded $(10 \mu \mathrm{L}$ on each well) onto Novex pH $3-7$ Isoelectric Focusing gels (Thermo Fisher Scientific). After isoelectric focusing separation, the gel was washed for $5 \mathrm{~min}$ in deionized water and then fixed in $12 \%$ trichloroacetic acid (TCA) for $30 \mathrm{~min}$. After fixation, the gel was washed 3 x 10 min with deionized water to remove TCA and subsequently stained in Coomassie Brilliant Blue R250 solution. 
For western blot analysis, the gel was treated according to Anderson \& Peck (2014) before blotting to PVDF membrane. Briefly, the gel was first washed for $5 \mathrm{~min}$ in deionized water and placed in $12 \%$ TCA at $5{ }^{\circ} \mathrm{C}$ overnight. Then the gel was washed $3 \times 10 \mathrm{~min}$ followed by incubation in resolubilization buffer (7 M urea, $2 \mathrm{M}$ thiourea, $5 \mathrm{mM}$ dithiothreitol) for $10 \mathrm{~min}$ and deionized water for $5 \mathrm{~min}$. Finally, the gel was incubated in SDS equilibration buffer (0.37 M Tris-HCl pH 8.8, 0.1\% SDS) for 3 x 5 min. The blotting and detection was carried out as described by Bao \& Ertbjerg (2015) except that the primary antibody chain (mouse monoclonal anti-myosin (Skeletal, Fast) antibody clone MY-32 (Sigma-Aldrich, Saint Louis)) was diluted 1:5000.

\subsection{Protein identification by nano-LC-MS/MS}

Selected protein bands in IEF gel were cut out of the gel and prepared for in-gel digestion. Disulfide bridges in proteins were reduced with $10 \mathrm{mM}$ dithiothreitol, $\mathrm{pH}$ 7.6, in $50 \mathrm{mM} \mathrm{NH} 4 \mathrm{HCO}_{3}$ at $60{ }^{\circ} \mathrm{C}$ for 1 h. Alkylation was performed for 30 minutes in $10 \mathrm{mM}$ iodoacetamide in $100 \mathrm{mM}$ Tris-HCl, $\mathrm{pH}$ 8.0. Gel slices were thoroughly rinsed with $50 \mathrm{mM} \mathrm{NH}_{4} \mathrm{HCO}_{3}$. Enzymatic digestion was done by adding 50 $\mu \mathrm{l}$ of trypsin solution $\left(5 \mathrm{ng} / \mu \mathrm{l}\right.$ trypsin in $50 \mathrm{mM} \mathrm{NH}_{4} \mathrm{HCO}_{3}$ ) and by incubating at room temperature overnight with gentle shaking. The supernatant was transferred to a clean protein LoBind tube. Trifluoroacetic acid (10\%) was added to the peptide supernatant to reach a pH between 2 and 4 . Peptide samples were measured by nLC-MS/MS with a Proxeon EASY nLC and a LTQ-Orbitrap XL mass spectrometer as previously described (Lu et al., 2011).

MaxQuant 1.5.2.8 was used for protein identification and quantitation of the LC-MS data (Cox \& Mann, 2008). The "Specific Trypsin/P" Digestion mode was used with maximally 2 missed cleavages and further default settings for the Andromeda search engine (Cox et al., 2011). The Maxquant 
proteinGroups result file was filtered to accept only proteins identified with at least two peptides of which at least one should be unique and at least one should be unmodified.

\subsection{Amino acid analysis}

Myofibrillar proteins were digested in $\mathrm{HCl}$ and the amino acids were derivatized with Waters (Milford, MA, USA) AccQ•Tag Ultra reagent and analyzed by ultra high performance liquid chromatography (UHPLC). Myofibrillar pellet (section 2.2; $14 \mathrm{mg}$ protein) was digested with $5 \mathrm{~mL}$ of $6 \mathrm{M} \mathrm{HCl}$ containing $2 \mathrm{mM}$ D-Norvaline (internal standard) and $0.1 \%$ phenol at $110^{\circ} \mathrm{C}$ for $24 \mathrm{~h}$. After digestion, $1 \mathrm{~mL}$ of sample was centrifuged at $15,000 \mathrm{~g}$ for $10 \mathrm{~min}$. An aliquot $(200 \mu \mathrm{L})$ of the supernatant was neutralized with $535 \mu \mathrm{L} 2 \mathrm{M} \mathrm{NaOH}$ followed by 4 times dilution with AccQ•Tag Ultra Borate buffer. Then $10 \mu \mathrm{L}$ of the neutralized and diluted sample was taken into a UHPLC vial and added $70 \mu \mathrm{L}$ Borate buffer and $20 \mu \mathrm{L} \mathrm{AccQ} \bullet$ Tag reagent. The reaction mixture was kept at room temperature for 1 min, heated at $55^{\circ} \mathrm{C}$ for $10 \mathrm{~min}$ and $1 \mu \mathrm{L}$ was injected after cooling.

UHPLC was performed on Acquity system (Waters) equipped with a Waters BEH C18 column (100 $\mathrm{mm} * 2.1 \mathrm{~mm}$, particle size $1.7 \mu \mathrm{m})$. The flow rate was $0.7 \mathrm{~mL} / \mathrm{min}$ and column temperature at $55^{\circ} \mathrm{C}$. The solvent system consisted of two eluents from Waters: (A) AccQ•Tag ultra eluent A, diluted 20 times (B) AccQ•Tag ultra eluent B. The following gradient was used: 0-0.54 min, 99.9\% A-0.1\% B; $5.74 \min , 90.9 \%$ A-9.1\% B; $7.74 \min , 78.8 \%$ A-21.2\% B; $8.04 \min , 40.4 \%$ A-59.6\% B; 8.05 min, $10 \%$ A-90\% B; $8.64 \min , 10 \%$ A-90\% B; $8.73 \min , 99.9 \%$ A-0.1\% B; $9.50 \min , 99.9 \%$ A-0.1\% B. The peaks were identified by the retention time of individual amino acid. The quantity was calculated based on peak areas of samples and known amount of standard amino acid mixtures. The amount of each amino acid was converted to mg per gram protein. 


\subsection{Determination of water-holding}

Eppendorf tubes of known weight $\left(\mathrm{W}_{0}\right)$ were used for the oxidation of myofibrils. After oxidation, washing and centrifugation (section 2.2), the weight of tubes (containing wet myofibril pellet) was recorded $\left(\mathrm{W}_{1}\right)$. Then the tubes were dried in an oven at $100^{\circ} \mathrm{C}$ for $6 \mathrm{~h}$, and the weight of tubes (containing dry myofibril protein pellet) was recorded $\left(\mathrm{W}_{2}\right)$. The water holding was defined using the following equation:

Water holding $\left(\mathrm{g} \mathrm{H}_{2} \mathrm{O} / \mathrm{g}\right.$ protein $)=\left(\mathrm{W}_{1}-\mathrm{W}_{2}\right) /\left(\mathrm{W}_{2}-\mathrm{W}_{0}\right)$

\subsection{Data analysis}

Two independent repetitions of the experiment were performed involving isolation and oxidation of myofibrils. For each repetition, one porcine longissimus thoracis et lumborum (LTL) muscle was used. Independent isolations of myofibrils were done for the various measurements followed by triplicate determinations of free thiol groups, particle size and amino acid analysis within each repetition. Six replicates was done for carbonyls measurement and eight replicates was done for water-holding determination. Data were analyzed by the IBM SPSS Statistics 24 software using one way ANOVA with concentration of $\mathrm{HClO}$ as fixed factor. Tukey HSD test was used to find significant differences at a level of $P<0.05$.

\section{Results}

\subsection{Protein oxidation}


Protein oxidation has previously been measured as a decline in free thiols and an increase in protein carbonyls. Incubation with hypochlorous acid greatly $(P<0.001)$ reduced the free thiols (Fig. 1$)$ of myofibrillar proteins and increased the content of carbonyls (Fig. 2). Around $40 \%$ of the free thiols were lost after incubation with $10 \mathrm{mM} \mathrm{HClO}$ compared to the control without oxidant, declining from $98 \mathrm{nmol} / \mathrm{mg}$ protein to $55 \mathrm{nmol} / \mathrm{mg}$ protein (Fig. 1). In parallel, the carbonyls increased from 2.0 $\mathrm{nmol} / \mathrm{mg}$ protein in the control to $11 \mathrm{nmol} / \mathrm{mg}$ protein at $10 \mathrm{mM} \mathrm{HClO}$ (Fig. 2).

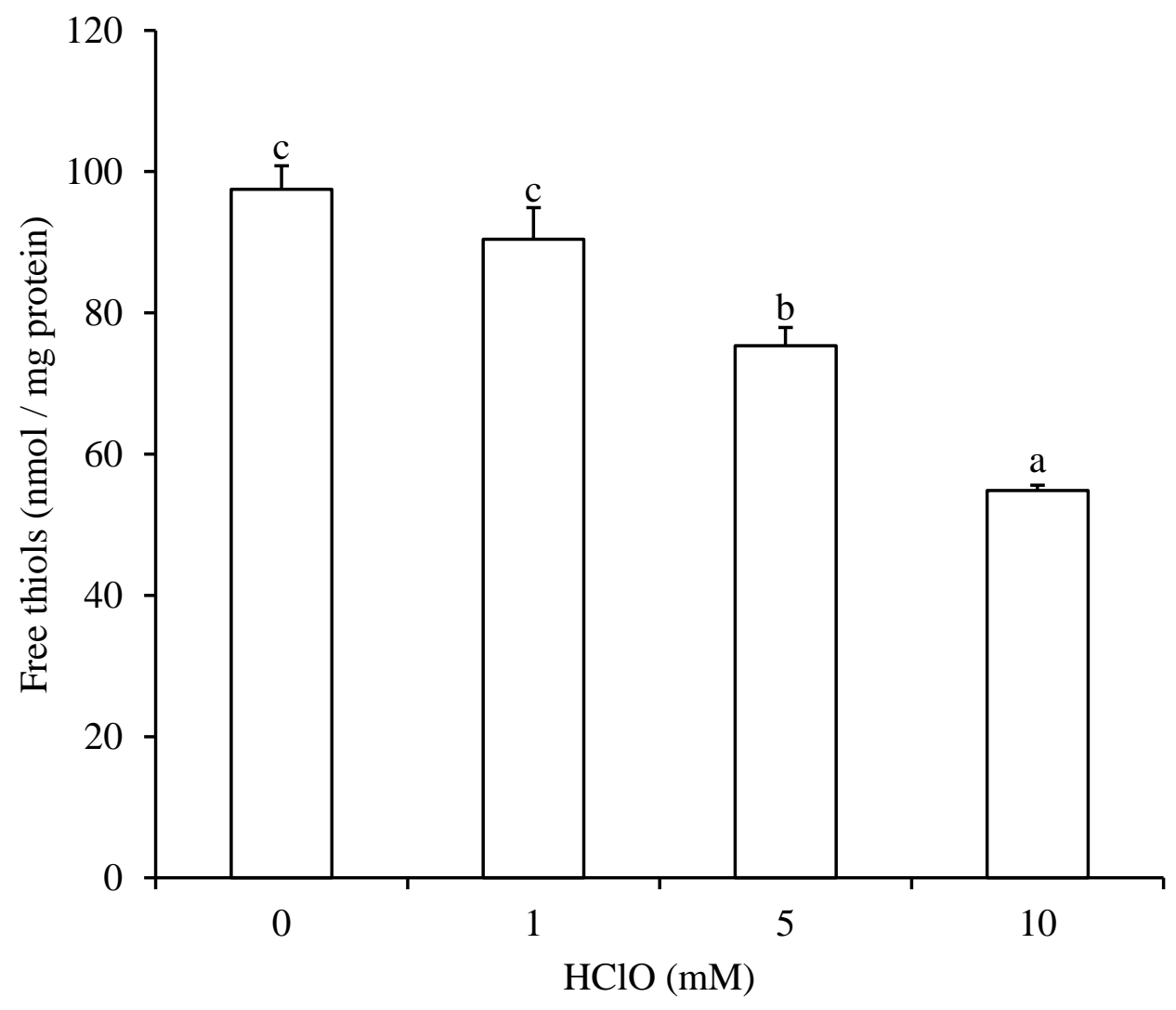

Fig. 1. Free thiol groups of myofibrillar proteins after oxidation with different concentrations of HCIO $(0,1,5$, and $10 \mathrm{mM})$. Means with standard deviations $(\mathrm{n}=6)$ are shown. ${ }^{\mathrm{a}-\mathrm{c}}$ Means with different letters differ $(P<0.05)$. 


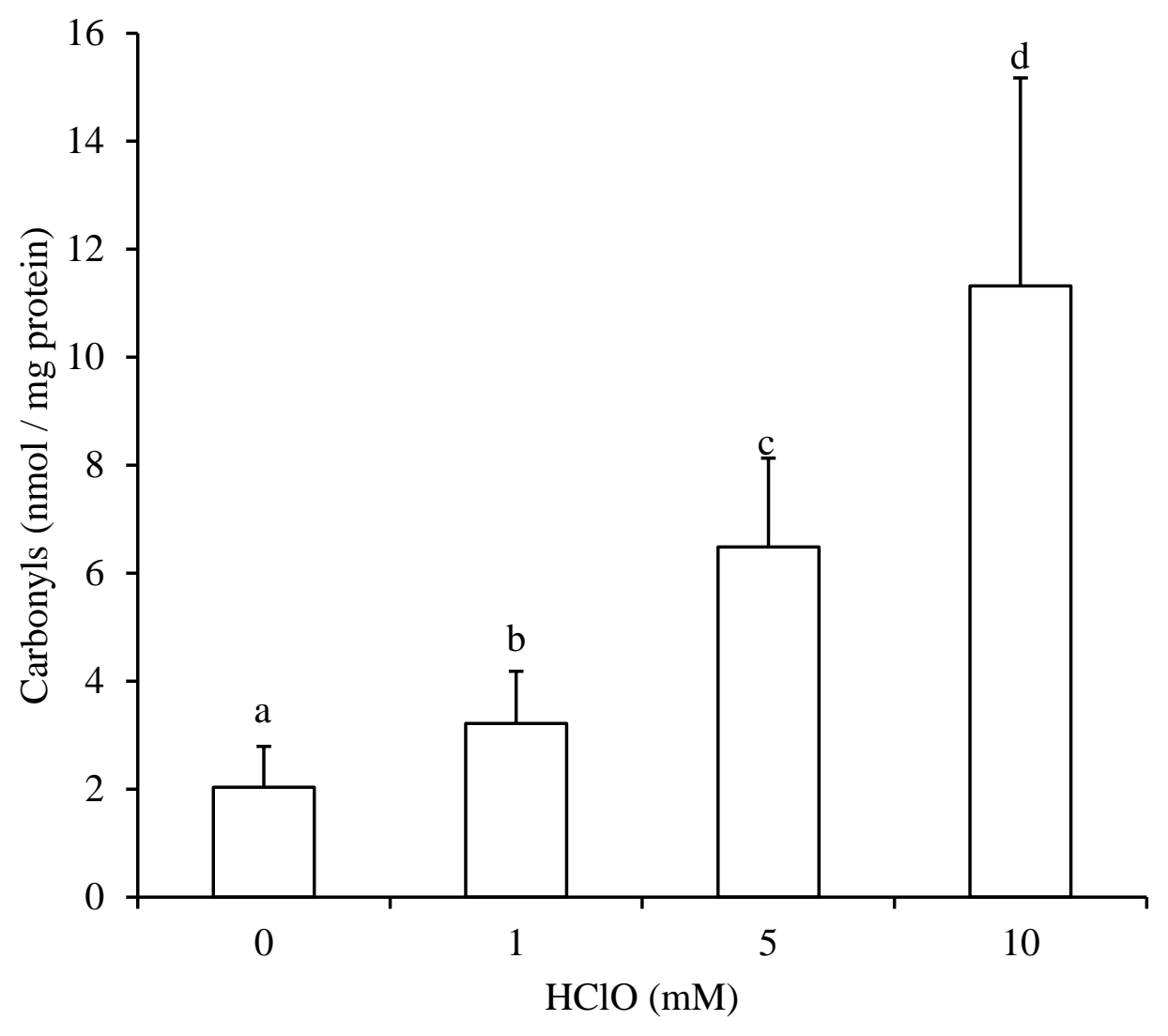

Fig. 2. Carbonyl content of myofibrillar proteins after oxidation with different concentrations of HClO $(0,1,5$, and $10 \mathrm{mM})$. Means with standard deviations $(n=12)$ are shown. ${ }^{\mathrm{a}-\mathrm{d}}$ Means with different letters differ $(P<0.05)$.

\subsection{Particle size}

Particle size measurement is increasingly used as a basic measurement in meat science and is often a critical parameter. It has been shown to be very useful in estimating myofibril fragmentation due to its convenience (Lametsch, Knudsen, Ertbjerg, Oksbjerg, \& Therkildsen, 2007). Here we used the particle size distribution of oxidized myofibrils to evaluate the structural changes due to oxidation. With increasing concentration of hypochlorous acid, the distribution curve of particle size shifted as the fraction of small particles decreased along with an increase in the faction of large particles (Fig. 3). All 
the reported statistical parameters $(D(\mathrm{v}, 0.1), D(\mathrm{v}, 0.5), D(\mathrm{v}, 0.9), D(3,2)$, and $D(4,3))$ increased $(P<$ 0.001) with increasing concentration of $\mathrm{HClO}$ (Table 1). The presented data clearly indicates that the myofibrils form larger particles upon oxidation, and thus illustrates pronounced aggregation of myofibrils.

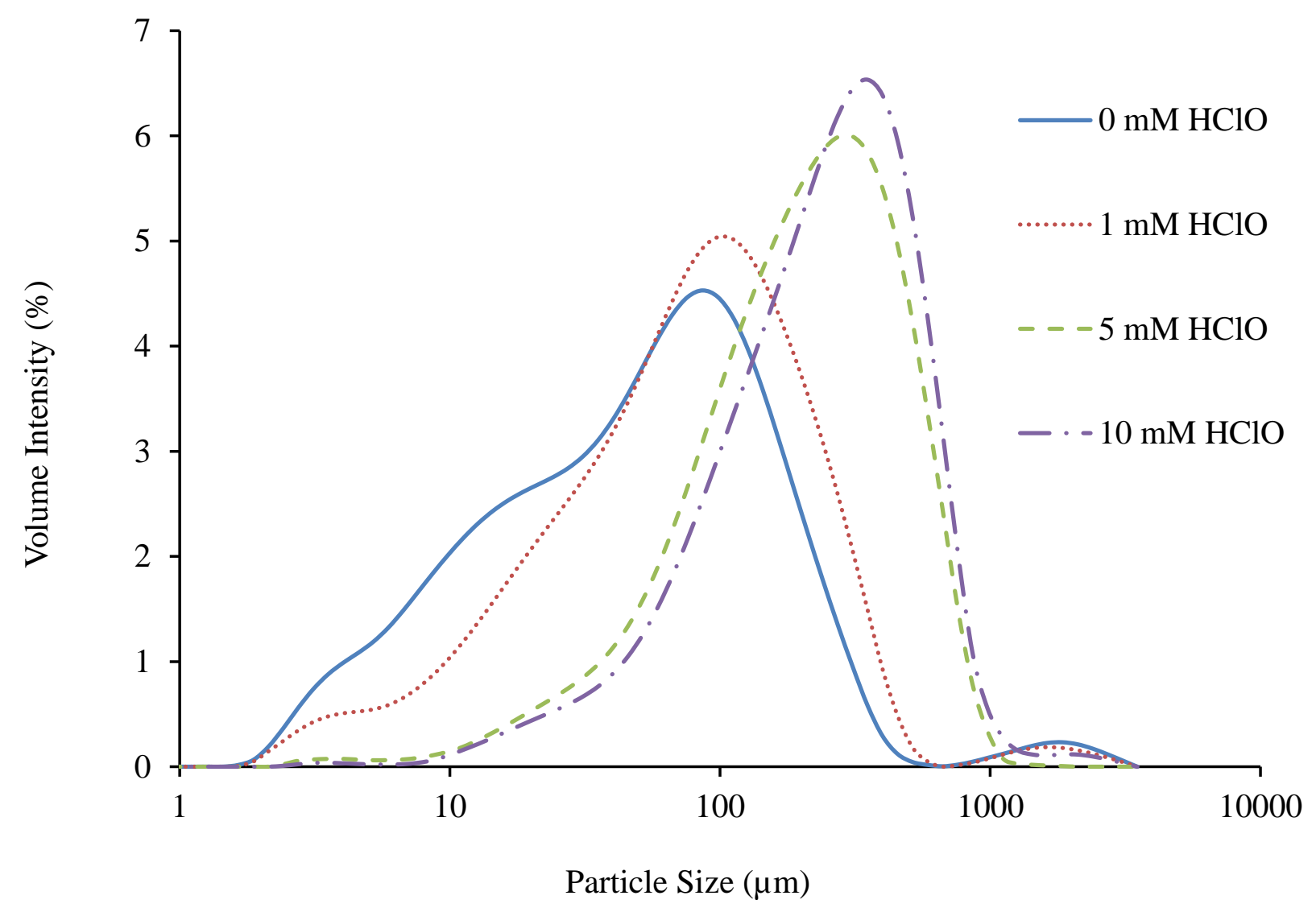

Fig. 3. Particle size distribution of myofibrils $(n=6)$ after oxidation with different concentrations of $\mathrm{HClO}(0,1,5$, and $10 \mathrm{mM})$. 
Table 1. Particle size $(\mu \mathrm{m})$ of myofibrils after oxidation with different concentrations of $\mathrm{HClO}(0,1,5$, and $10 \mathrm{mM})$.

\begin{tabular}{cccccc}
\hline$\mu \mathrm{m}$ & \multicolumn{4}{c}{$\mathrm{HClO}(\mathrm{mM})$} & SEM \\
\cline { 2 - 5 } & 0 & 1 & 5 & 10 & \\
\hline$D(\mathrm{v}, 0.1)$ & $8^{\mathrm{a}}$ & $15^{\mathrm{b}}$ & $57^{\mathrm{c}}$ & $69^{\mathrm{d}}$ & 4 \\
$D(\mathrm{v}, 0.5)$ & $56^{\mathrm{a}}$ & $83^{\mathrm{b}}$ & $226^{\mathrm{c}}$ & $269^{\mathrm{d}}$ & 13 \\
$D(\mathrm{v}, 0.9)$ & $292^{\mathrm{a}}$ & $251^{\mathrm{a}}$ & $562^{\mathrm{ab}}$ & $659^{\mathrm{b}}$ & 41 \\
$D(3,2)$ & $22^{\mathrm{a}}$ & $34^{\mathrm{a}}$ & $110^{\mathrm{b}}$ & $134^{\mathrm{c}}$ & 7 \\
$D(4,3)$ & $80^{\mathrm{a}}$ & $133^{\mathrm{a}}$ & $273^{\mathrm{b}}$ & $322^{\mathrm{b}}$ & 15 \\
\hline
\end{tabular}

$\overline{\mathrm{a}-\mathrm{d}}$ Means $(\mathrm{n}=6)$ in the same row with different superscripts differ, $P<0.05$.

SEM: standard error of the mean.

\subsection{Isoelectric focusing and western blot}

Myofibrillar proteins were extracted following oxidation and separated according to their isoelectric point (pI) (Fig. 4). The isoelectric focusing gel showed that the $\mathrm{pI}$ of the proteins generally shifted to a slightly more acidic area (Box $1-4$, Fig. 4A). The proteins in Box 1 and 2 were recognized by the myosin heavy chain antibody (Fig. 4B) and thus contained myosin heavy chain, and the dominating protein bands migrated to a slightly lower position in the $10 \mathrm{mM} \mathrm{HClO}$ group compared to the nonoxidized control, indicating that the $\mathrm{pI}$ value of the myosin heavy chain had shifted towards the acidic area. Box 3 (pI around 5.4) mainly contained tropomyosin, actin and myosin light chain and Box 4 (pI around 5.2) mainly contained actin and myosin light chain as identified by mass spectroscopy (Fig. 4C). 

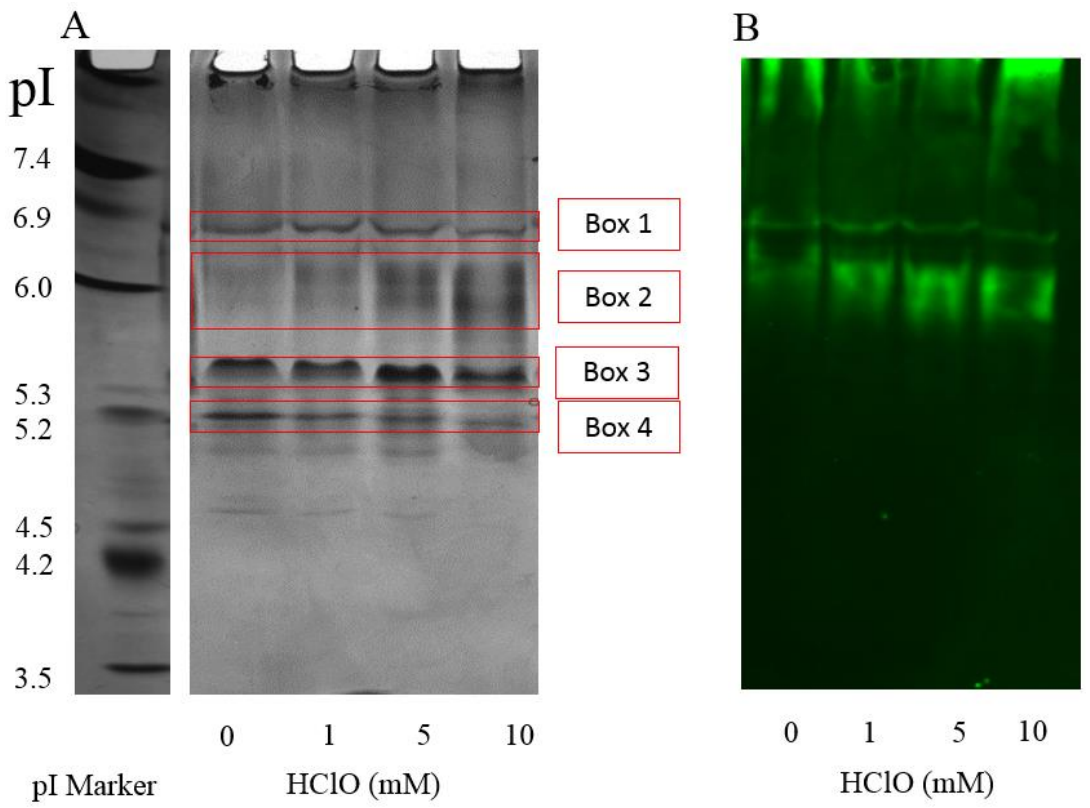

\begin{tabular}{|l|l|l|}
\hline Gel area & $\begin{array}{l}\text { Dominant proteins } \\
\text { identified }\end{array}$ & $\begin{array}{l}\text { Locations in the } \\
\text { sarcomere }\end{array}$ \\
\hline${ }^{\text {a} B o x ~ 1 ~}$ & Myosin heavy chain & Myosin filament \\
\hline${ }^{\text {a Box } 2}$ & Myosin heavy chain & Myosin filament \\
\hline${ }^{\text {b} B o x ~ 3 ~}$ & Myosin light chain & Myosin filament \\
\cline { 2 - 3 } & Tropomyosin & Actin filament \\
\cline { 2 - 3 } & Actin & Actin filament \\
\hline${ }^{\text {b Box 4 }}$ & Actin & Actin filament \\
\cline { 2 - 3 } & Myosin light chain & Myosin filament \\
\hline
\end{tabular}

Fig. 4. Representative isoelectric focusing gel of porcine myofibrillar proteins oxidized with various amounts of $\mathrm{HClO}(0,1,5$, and $10 \mathrm{mM})$ and stained with Coomassie Brilliant Blue R-250 (A) or antibody towards myosin heavy chain (B). The inserted table (C) shows the identity and location in

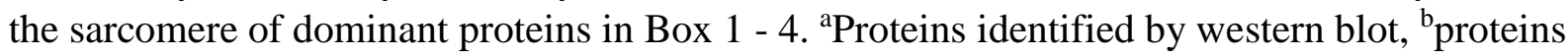
identified by nanoLC-MS/MS.

By definition, $\mathrm{pI}$ is the $\mathrm{pH}$ at which the protein molecule has a net charge of zero. Therefore, the lower pI following oxidation suggests that protein net charges in the myofibrils became more negative. It should be noted that a fraction of the strongly oxidized myofibrils remained insoluble and the IEF gel, therefore, only shows that part of the oxidized proteins that more easily are brought into solution. 


\subsection{Amino acid analysis}

To study the more insoluble part of oxidized proteins, the myofibrillar proteins were subjected to amino acid analysis. The highest $\mathrm{HClO}$ level led to a $14 \%$ decrease $(P=0.03)$ of histidine as compared to the control, while no significant changes of the other analyzed amino acids were found $(P>0.05)$ (Table 2). Under the experimental $\mathrm{pH}$ of 5.5, the histidine residue would mainly exist in the protonated form and thus carry a positive charge (the pKa of its side chain is about 6.0 ). The oxidation of histidine will likely lead to formation of a carbonyl group in 2-oxo-histidine and therefore to loss of positive charges from myofibrillar proteins.

Table 2. Amino acid composition (means with standard errors, $n=6$ ) of myofibrillar proteins after oxidation with different concentrations of $\mathrm{HClO}(0,1,5$, and $10 \mathrm{mM})$.

\begin{tabular}{|c|c|c|c|c|c|c|}
\hline \multirow{2}{*}{$\begin{array}{l}\text { Amino acids }{ }^{1} \\
(\mathrm{mg} / \mathrm{g} \text { protein) }\end{array}$} & \multicolumn{4}{|c|}{$\mathrm{HClO}(\mathrm{mM})$} & \multirow[t]{2}{*}{ SEM } & \multirow[t]{2}{*}{$P$-value } \\
\hline & 0 & 1 & 5 & 10 & & \\
\hline His & 17.7 & 17.8 & 16.3 & 15.3 & 0.37 & 0.03 \\
\hline Ser & 32.4 & 32.7 & 31.4 & 30.6 & 0.51 & 0.46 \\
\hline Arg & 58.4 & 58.8 & 55.3 & 53.7 & 1.05 & 0.28 \\
\hline Gly & 27.3 & 27.7 & 26.0 & 25.4 & 0.49 & 0.34 \\
\hline $\mathrm{Asx}^{2}$ & 69.6 & 71.1 & 69.4 & 69.7 & 1.00 & 0.94 \\
\hline $\mathrm{Glx}^{3}$ & 135.7 & 136.9 & 132.0 & 130.0 & 1.95 & 0.59 \\
\hline Thr & 37.6 & 37.8 & 36.1 & 35.3 & 0.59 & 0.40 \\
\hline Ala & 44.9 & 45.7 & 43.8 & 43.0 & 0.67 & 0.56 \\
\hline Pro & 25.5 & 26.0 & 25.0 & 24.4 & 0.39 & 0.51 \\
\hline Lys & 65.5 & 67.4 & 66.1 & 65.6 & 0.85 & 0.87 \\
\hline Tyr & 32.9 & 32.8 & 26.9 & 29.5 & 1.24 & 0.26 \\
\hline Val & 35.3 & 35.7 & 36.8 & 38.1 & 0.50 & 0.20 \\
\hline Ile & 34.7 & 36.5 & 37.6 & 40.7 & 0.94 & 0.14 \\
\hline Leu & 60.0 & 64.7 & 62.9 & 59.1 & 1.20 & 0.35 \\
\hline Phe & 36.7 & 39.3 & 38.9 & 37.3 & 0.92 & 0.73 \\
\hline
\end{tabular}

${ }^{1}$ Trp, Cys, and Met are not included in the analysis.

${ }^{2}$ Asx represents combined Asp and Asn.

${ }^{3}$ Glx represents combined Glu and Gln.

SEM: standard error of the mean. 


\subsection{Water-holding}

In this study, the water-holding of myofibrils was defined as the amount of water kept in the myofibril pellet per gram protein. It was evaluated by a centrifugation method similar to previous studies (Liu, Arner, Puolanne, \& Ertbjerg, 2016). Generally, oxidation with hypochlorous acid increased $(P<$ 0.001) the water-holding of myofibrils (Fig. 5). Incubation with $10 \mathrm{mM} \mathrm{HClO}$ led to about $11 \%$ more water bound as the water-holding increased to $7.3 \mathrm{~g} \mathrm{H}_{2} \mathrm{O}$ / g protein as compared to $6.6 \mathrm{~g} \mathrm{H}_{2} \mathrm{O} / \mathrm{g}$ protein in the non-oxidized control.

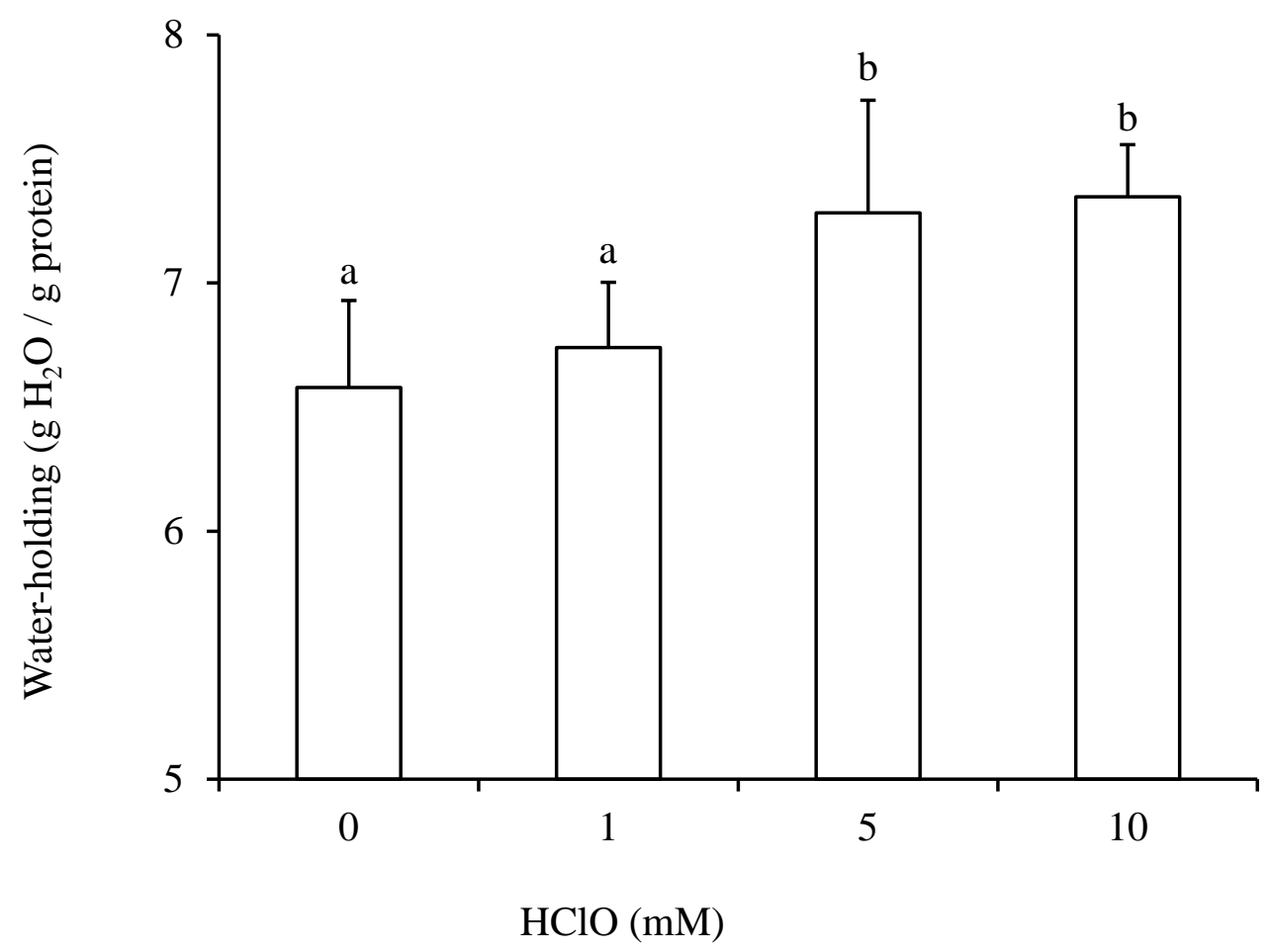

Fig. 5. Water-holding of myofibrils after oxidation with different concentrations of $\mathrm{HClO}(0,1,5$, and $10 \mathrm{mM})$. Means with standard deviations $(\mathrm{n}=16)$ are shown. ${ }^{\mathrm{a}-\mathrm{b}}$ Means with different letters differ $(P<0.05)$. 


\section{Discussion}

In the present study, we investigated water-holding of chemically oxidized myofibrils and found that protein oxidation led to loss of histidine residues (Table 2) together with a greater content of carbonyls (Fig. 2), increased particle size (Fig. 3), increased net negative charges of the fraction of proteins in myofilaments that were solubilized before IEF (Fig. 4) and improved water-holding of myofibrils (Fig. 5). Based on these results, we here propose the following mechanism of oxidation-induced changes in protein aggregation, filament charges, and water-holding (Fig. 6).

A

Myofibrils

B

Sarcomere

C

Amino acid residue

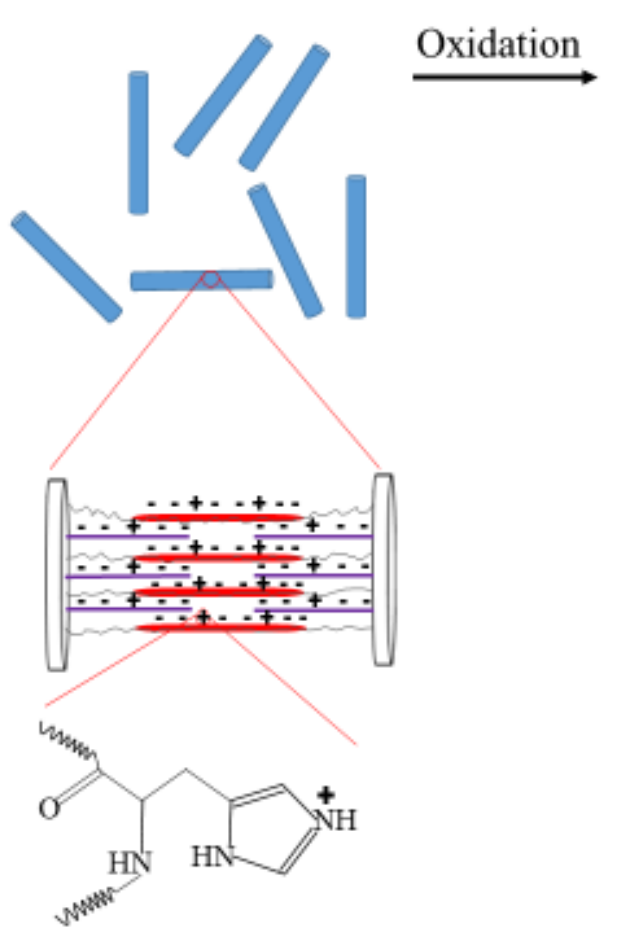

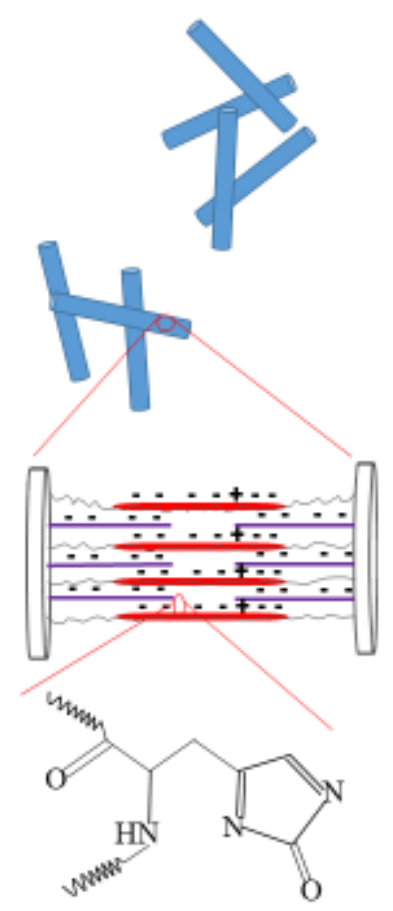

Fig. 6. Model for the effect of myofibrillar protein oxidation on filament charges, protein aggregation and water-holding. Oxidation leads to two major changes with opposite effects on waterholding: 1) Oxidation leads to aggregation of myofibrils which tends to decrease water-holding (A); 2) Conversely, within the sarcomere an increase in net negative charges of both myosin and actin filaments tends to improve water-holding (B). The change in filament charges on amino acid level is illustrated in $(\mathrm{C})$, where a positively charged histidine residue forms 2-oxo-histidine following oxidation and loses its positive charge, and thereby causes an increase in the net negative charges of myofilaments. 
Upon oxidation, the loss of free thiol groups and increase in particle size indicate formation of protein cross-links and aggregates which act to inhibit swelling of myofibrils. An opposite effect from electrostatic charges is simultaneously promoting swelling. Histidine side chains are carbonylated to form 2-oxohistidine whereby positive charges are reduced. As a consequence, the overall net negative charges in myofibrillar proteins including myosin, actin and tropomyosin increase with oxidation which leads to increased net negative charges on both myosin and actin filaments. More net negative charges on the myofilaments cause greater swelling pressure, which is linked to better water-holding (Offer \& Trinick, 1983). The overall result of protein oxidation on water-holding is therefore a balance between promoting factors (such as increased net charges) and inhibiting factors (such as protein crosslinking and aggregation).

It has been suggested that protein oxidation in meat lead to an alteration in electronic arrangement, and thereby affects the chemical interaction between myofibrillar proteins and water molecules (Estévez et al., 2011). Also Baraibar et al. (2011) reported that some proteins involved in the oxidative stress response in human myoblasts were shifted to a more acidic $\mathrm{pI}$ upon oxidative stress. In agreement, the present study found that the isoelectric point of oxidized proteins that are solubilized were shifted to a more acidic area in the IEF gel (Fig. 4). At pH around 5.0, both myosin and actin filaments have a low or zero net charge (Offer and Knight, 1988). In the present study the $\mathrm{pH}$ was around 5.5, and hence both filaments were net negatively charged. After oxidation, the pI of solubilized myofibrillar proteins generally shifted to a more acidic area and the affected proteins were mainly identified as myosin heavy chain, myosin light chain, actin and tropomyosin, all of which are located in either myosin- or actin filaments. Myosin, actin and tropomyosin together account for about $73 \%$ of the total myofibrillar protein and the observed changes (Fig. 4) is therefore likely able to lower the pI of myofilaments. Consequently, the difference between the isoelectric point of myofilaments and their 
environmental $\mathrm{pH}$ of 5.5 would be larger following oxidation, indicating an overall increase in net negative charges of myofilaments.

One mechanism that oxidation may affect protein charges is through protein carbonylation which involves the loss of positively charged amino acids such as lysine, arginine and histidine (Stadtman, 1993; Utrera \& Estévez, 2012). The loss of a positively charged amino acid will increase the overall net negative charge. Histidine and lysine are major targets for oxidative modification and the histidine derived carbonyl, 2-oxo-histidine, has been detected in several proteins subjected to in vitro oxidation (Uchida, 2003). Park \& Xiong (2007) found that oxidative modifications on amino acids depend on the oxidizing system. Specific protein carbonyls, such as lysine-derived $\alpha$-aminoadipic semialdehydes (AAS) and arginine or proline derived $\gamma$-glutamic semialdehydes (GGS) have been suggested to be major products of protein oxidation in meat (Estévez, 2011). The present study suggests that also histidine is a major target of oxidative reactions in postmortem muscle. Another mechanism whereby oxidation can affect protein charges may be protein denaturation and unfolding. According to Sun, Zhou, Sun, \& Zhao (2013), protein oxidation may expose buried hydrophobic groups and induce an increase in the number of ionized groups, causing an increase in net negative charges.

As the charges of a protein is critical to its biochemical properties, oxidation-induced changes in net negative charges may be one of the key factors to understand the functionality of oxidized proteins. Protein net charges have been linked to protein functionality in meat such as the emulsifying properties of myofibrillar proteins (Sun et al., 2013). Utrera \& Estévez (2012) found that protein carbonylation correlates to many functionality indicators (solubility, water-holding, foaming, etc. ) and they suggested that loss of protonable amino acids would lead to an alteration of the overall charge arrangement of myofibrillar proteins, and therefore affect funtional properties of proteins. Liu et al. (2016) studied effect of sarcoplasmic protein denaturation on water-holding of myofibrils and hypothesized that denatured 
sarcoplasmic proteins may precipitate onto the surface of myofilaments. The denatured sarcoplasmic proteins was suggested to add positive charges to the overall negatively charged filaments and thus decrease the net charge and subsequently the electrical repulsion - an effect which would be able to explain an observed decrease in the distance between actin and myosin filaments due to sarcoplasmic protein denaturation..

In our study, myofibrils were used to investigate the effect of oxidation on water-holding. Previous studies mainly focused on oxidation-induced changes in myofibrillar structures. Huff-Lonergan \& Lonergan (2005) suggested that oxidation may reduce the proteolytic degradation of myofibrillar proteins, including proteins in costameric linkages. Kristensen \& Purslow (2001) suggested that proteolysis of costamers plays an important role in water-holding of meat. The costameres can act as a structural constraint and limit the swelling of myofibers. Recently, Zeng, Li, \& Ertbjerg (2017) showed that proteolytic degradation of proteins in and around the Z-disk is also a determining factor for increased swelling of myofibrils, and thereby affect water-holding of myofibrils. Protein oxidation has also been suggested to inhibit swelling of myofibrils due to structural constraint of oxidation-induced disulfide cross-links (Liu et al., 2009).

If structural constraint is the only factor affecting water-holding of oxidized meat, we would expect decreased water-holding following oxidation. However, we observed increased water-holding with oxidation (Fig. 5), suggesting that other factors exerted stronger effects on water-holding. Oxidation led to a shift of $\mathrm{pI}$ of both myosin and actin towards the more acidic area, suggesting an increase in net negative charges due to oxidative modification of histidine. This would lead to increased net negative charges on myosin and actin filaments. In addition, fragmentation of peptides upon oxidation may produce additional charges to myofibrillar proteins. An increase in filament net charges is generally believed to improve water-holding of meat. Therefore, in this study, the oxidation-induced increase in 
water-holding was likely driven by increased net charges on myofilaments whereas opposing effects of protein cross-linking and aggregation did not balance out or overrule the effects of increased net negative charges. This balance may, however, differ depending on a variety of factors which can explain why there is no general agreement on the effect of protein oxidation on water-holding.

Protein oxidation can eventually lead to intra- and inter-molecular cross-linking and protein aggregation (Estévez, 2011; Lund et al., 2011). Therefore, it was expected that the particle size of oxidized myofibrils became larger (Fig. 3, Table 1). In agreement, we previously reported (Bao et al., 2016) that when minced beef was packaged under high oxygen atmosphere, protein oxidation was induced and resulted an increased particle size of both raw meat and cooked meat. Protein cross-links or aggregates altered the myofibrillar structure, which may limit the swelling of myofibrils and therefore have a negative effect on water-holding.

In addition to filament net charges and protein cross-linking, chaotropic (structure-breaking) and kosmotropic (structure-making) effects may play a role on oxidation-induced changes in water-holding. The positively charged histidine residues in myofibrillar proteins are strong chaotropes which make water molecules less structured and more mobile (Collins, 1997) and chaotropic effects are hypothesized to be linked to reduced water-holding (Puolanne \& Halonen, 2010). Formation of carbonyls from histidine will likely reduce the chaotropic effect and therefore increase water-holding. In the present study, myofibrils were used as a model to investigate the effect of protein oxidation on water-holding. However, additional factors such as the presence of sarcoplasmic proteins, sarcolemma and connective tissue may be of importance to understand the role of protein oxidation on waterholding in fresh meat. 


\section{Conclusion}

Oxidation of myofibrils resulted in greater loss of free thiol groups, loss of histidine residues and formation of carbonyls in myofibrillar proteins and generally induced larger particle size. The myofibrillar proteins myosin, actin and tropomyosin were identified in protein bands that shifted to a more acidic isoelectric point upon oxidation, suggesting an increase in net negative charges of myofilaments. The water-holding of myofibrils were generally improved following oxidation. The overall net negative charges of myofilaments provide a novel perspective to understand oxidation-induced meat quality changes related to water-holding. We here propose a hypothesis that water-holding of oxidized meat is a balance between promoting factors such as oxidation-induced net negative charges and opposing factors such as crosslinking and aggregation due to oxidation. However, the oxidation system was based on $\mathrm{HClO}$ alone, and it would be of interest to extend the study to other model systems and meat products.

\section{Acknowledgments}

The authors would like to thank the China Scholarship Council for financial support; Simon Allegaert and Cristina Ababei for analytical help; Minnamari Edelmann and Miikka Olin for help in determination of amino acids and professor emeritus Eero Puolanne for his valuable comments on the manuscript.

\section{References}

Anderson, J. C., \& Peck, S. C. (2014). Detection of protein phosphorylation and charge isoforms using vertical one-dimensional isoelectric focusing gels. Plant MAP Kinases: Methods and Protocols, 39-46. 
Bao, Y., \& Ertbjerg, P. (2015). Relationship between oxygen concentration, shear force and protein oxidation in modified atmosphere packaged pork. Meat Science, 110, 174-179.

Bao, Y., Puolanne, E., \& Ertbjerg, P. (2016). Effect of oxygen concentration in modified atmosphere packaging on color and texture of beef patties cooked to different temperatures. Meat Science, $121,189-195$.

Baraibar, M. A., Hyzewicz, J., Rogowska-Wrzesinska, A., Ladouce, R., Roepstorff, P., Mouly, V., \& Friguet, B. (2011). Oxidative stress-induced proteome alterations target different cellular pathways in human myoblasts. Free Radical Biology and Medicine, 51, 1522-1532.

Chen, L., Zhou, G., \& Zhang, W. (2015). Effects of high oxygen packaging on tenderness and water holding capacity of pork through protein oxidation. Food and Bioprocess Technology, 8, 22872297.

Clausen, I., Jakobsen, M., Ertbjerg, P., \& Madsen, N. T. (2009). Modified atmosphere packaging affects lipid oxidation, myofibrillar fragmentation index and eating quality of beef. Packaging Technology and Science, 22, 85-96.

Collins, K. D. (1997). Charge density-dependent strength of hydration and biological structure. Biophysical Journal, 72, 65-76.

Cox, J., \& Mann, M. (2008). MaxQuant enables high peptide identification rates, individualized ppbrange mass accuracies and proteome-wide protein quantification. Nature Biotechnology, 26, 1367-1372.

Cox, J., Neuhauser, N., Michalski, A., Scheltema, R. A., Olsen, J. V., \& Mann, M. (2011). Andromeda: a peptide search engine integrated into the MaxQuant environment. Journal of Proteome Research, 10, 1794-1805. 
Decker, E. A., Xiong, Y. L., Calvert, J. T., Crum, A. D., \& Blanchard, S. P. (1993). Chemical, physical, and functional properties of oxidized turkey white muscle myofibrillar proteins. Journal of Agricultural and Food Chemistry, 41, 186-189.

Delles, R. M., \& Xiong, Y. L. (2014). The effect of protein oxidation on hydration and water-binding in pork packaged in an oxygen-enriched atmosphere. Meat Science, 97, 181-188.

Ellman, G. L. (1959). Tissue sulfhydryl groups. Archives of biochemistry and biophysics, 82, 70-77.

Estévez, M. (2011). Protein carbonyls in meat systems: A review. Meat Science, 89, 259-279.

Estévez, M., \& Luna, C. (2017). Dietary protein oxidation: A silent threat to human health? Critical Reviews in Food Science and Nutrition, 57, 3781-3793.

Estévez, M., Ventanas, S., Heinonen, M., \& Puolanne, E. (2011). Protein carbonylation and waterholding capacity of pork subjected to frozen storage: Effect of muscle type, premincing, and packaging. Journal of Agricultural and Food Chemistry, 59, 5435-5443.

Hamm, R. (1986). Functional properties of the myofibrillar system and their measurements. In Bechtel, P. J. (Eds). Muscle as food. Food Science and Technology (pp. 135-191). London: Academic Press Inc.

Huff-Lonergan, E., \& Lonergan, S. M. (2005). Mechanisms of water-holding capacity of meat: The role of postmortem biochemical and structural changes. Meat Science, 71, 194-204.

Kristensen, L., \& Purslow, P. P. (2001). The effect of ageing on the water-holding capacity of pork: Role of cytoskeletal proteins. Meat Science, 58, 17-23.

Lametsch, R., Knudsen, J. C., Ertbjerg, P., Oksbjerg, N., \& Therkildsen, M. (2007). Novel method for determination of myofibril fragmentation post-mortem. Meat Science, 75, 719-724.

Lindahl, G., Lagerstedt, Å., Ertbjerg, P., Sampels, S., \& Lundström, K. (2010). Ageing of large cuts of beef loin in vacuum or high oxygen modified atmosphere - Effect on shear force, calpain activity, desmin degradation and protein oxidation. Meat Science, 85, 160-166. 
Liu, J., Arner, A., Puolanne, E., \& Ertbjerg, P. (2016). On the water-holding of myofibrils: Effect of sarcoplasmic protein denaturation. Meat Science, 119, 32-40.

Liu, Z., Xiong, Y. L., \& Chen, J. (2009). Identification of restricting factors that inhibit swelling of oxidized myofibrils during brine irrigation. Journal of Agricultural and Food Chemistry, 57, 10999-11007.

Łopacka, J., Półtorak, A., \& Wierzbicka, A. (2017). Effect of reduction of oxygen concentration in modified atmosphere packaging on bovine M. longissimus lumborum and M. gluteus medius quality traits. Meat Science, 124, 1-8.

Lu, J., Boeren, S., de Vries, S. C., van Valenberg, H. J. F., Vervoort, J., \& Hettinga, K. (2011). Filteraided sample preparation with dimethyl labeling to identify and quantify milk fat globule membrane proteins. Journal of Proteomics, 75, 34-43.

Lund, M. N., Heinonen, M., Baron, C. P., \& Estevez, M. (2011). Protein oxidation in muscle foods: A review. Molecular Nutrition \& Food Research, 55, 83-95.

Lund, M. N., Lametsch, R., Hviid, M. S., Jensen, O. N., \& Skibsted, L. H. (2007). High-oxygen packaging atmosphere influences protein oxidation and tenderness of porcine longissimus dorsi during chill storage. Meat Science, 77, 295-303.

Morris, J. C. (1966). The acid ionization constant of $\mathrm{HOCl}$ from 5 to $35^{\circ}$. The Journal of Physical Chemistry, 70, 3798-3805.

Offer, G., \& Knight, P. (1988). Structural basis of water-holding in meat. Part 1: General principles and water uptake in meat processing. In R. Lawrie (Ed.), Developments in Meat Science, Vol 4 (pp. 63-171). London: Elsevier Applied Science.

Offer, G., \& Trinick, J. (1983). On the mechanism of water holding in meat: The swelling and shrinking of myofibrils. Meat Science, 8, 245-281. 
Park, D., \& Xiong, Y. L. (2007). Oxidative modification of amino acids in porcine myofibrillar protein isolates exposed to three oxidizing systems. Food Chemistry, 103, 607-616.

Puolanne, E., \& Halonen, M. (2010). Theoretical aspects of water-holding in meat. Meat Science, 86, 151-165.

Sekar, A., Dushyanthan, K., Radhakrishnan, K., \& Babu, R. N. (2006). Effect of modified atmosphere packaging on structural and physical changes in buffalo meat. Meat Science, 72, 211-215.

Soglia, F., Petracci, M., \& Ertbjerg, P. (2016). Novel DNPH-based method for determination of protein carbonylation in muscle and meat. Food Chemistry, 197, 670-675.

Stadtman, E. R. (1993). Oxidation of free amino acids and amino acid residues in proteins by radiolysis and by metal-catalyzed reactions. Annual Review of Biochemistry, 62, 797-821.

Sun, W., Zhou, F., Sun, D.-W., \& Zhao, M. (2013). Effect of oxidation on the emulsifying properties of myofibrillar proteins. Food and Bioprocess Technology, 6, 1703-1712.

Uchida, K. (2003). Histidine and lysine as targets of oxidative modification. Amino Acids, 25, 249-257.

Utrera, M., \& Estévez, M. (2012). Oxidation of myofibrillar proteins and impaired functionality: underlying mechanisms of the carbonylation pathway. Journal of Agricultural and Food Chemistry, 60, 8002-8011.

Wang, H., Luo, Y., \& Ertbjerg, P. (2017). Myofibrillar protein gel properties are influenced by oxygen concentration in modified atmosphere packaged minced beef. Food Chemistry, 230, 475-481.

Yang, X., Zhang, Y., Zhu, L., Han, M., Gao, S., \& Luo, X. (2016). Effect of packaging atmospheres on storage quality characteristics of heavily marbled beef longissimus steaks. Meat Science, 117, $50-56$.

Zeng, Z., Li, C., \& Ertbjerg, P. (2017). Relationship between proteolysis and water-holding of myofibrils. Meat Science, 131, 48-55. 